\title{
Coral recruitment is impacted by the presence of a sponge community
}

\author{
Marilyn E. Brandt ${ }^{1}$ (C) $\cdot$ Lauren K. Olinger ${ }^{1,2} \cdot$ Andia Chaves-Fonnegra $^{1,3,4} \cdot$ Julie B. Olson $^{5} \cdot$ Deborah J. Gochfeld $^{3,6}$
}

Received: 5 September 2018 / Accepted: 1 March 2019 / Published online: 14 March 2019

(c) The Author(s) 2019

\begin{abstract}
As coral cover has declined on Caribbean reefs, space has become occupied by other benthic taxa, including sponges, which may affect the recruitment of new corals, thereby affecting the ability of reefs to recover to coral-dominated states. Sponges may inhibit coral recruitment by pre-empting potential recruitment space, overgrowing recruits, or through allelopathy. This study examined coral recruitment across six coral reef sites surrounding St. Thomas, US Virgin Islands, and the impact of one species of sponge and the sponge community as a whole on coral recruitment. To test the effect of a single species of sponge on coral recruitment, fragments of living or non-living Aplysina cauliformis were attached to terracotta recruitment tiles and deployed at all six sites, along with unoccupied tiles as controls. At two of the sites, a community-level experiment consisted of deploying recruitment tiles in $1 \mathrm{~m}^{2}$ plots that were either cleared of the entire sponge community or control plots where no sponges were removed. Recruitment rates showed a consistent difference among sites over multiple years and experiments. Results of the species-specific experiment showed that the proximity of live or dead A. cauliformis did not affect coral recruitment. However, results of the community-level experiment found greater coral recruitment rates in plots cleared of sponges, suggesting that the presence of the sponge community negatively affected coral recruitment. This study is one of the first to experimentally test and find a significant impact of sponges on coral recruitment, and highlights the need for additional research in this area.
\end{abstract}

Responsible Editor: L. Mydlarz.

Revieved by R. Ritson-Williams and R. Ruzicka.

Electronic supplementary material The online version of this article (https://doi.org/10.1007/s00227-019-3493-5) contains supplementary material, which is available to authorized users.

Marilyn E. Brandt

mbrandt@uvi.edu

1 Center for Marine and Environmental Studies, University of the Virgin Islands, 2 John Brewers Bay, St. Thomas, VI 00802, USA

2 Department of Biology and Marine Biology, University of North Carolina Wilmington, Wilmington, NC 28407, USA

3 Department of BioMolecular Sciences, University of Mississippi, P.O. Box 1848, University, MS 38677, USA

4 Harbor Branch Oceanographic Institute/Harriet L. Wilkes Honors College, Florida Atlantic University, 5600 N US Highway 1, Fort Pierce, FL 34946, USA

5 Department of Biological Sciences, University of Alabama, Tuscaloosa, AL 35487, USA

6 National Center for Natural Products Research, University of Mississippi, P.O. Box 1848, University, MS 38677, USA

\section{Introduction}

Changes in Caribbean coral reef communities have been exacerbated by the dramatic loss of reef-building coral observed over the last several decades (Eakin et al. 2010; Hughes 1994). Coral reefs once dominated by living coral are now more likely dominated by macroalgae and other benthic organisms, particularly sponges, which can represent significant diversity and biomass on Caribbean reefs (Wilkinson and Cheshire 1990; Gochfeld et al. 2007; Maliao et al. 2008; Norström et al. 2009). As a result of a multitude of stressors affecting coral reef communities and changing reef community structure, competition between reef-building corals and sponges is becoming increasingly common worldwide (Chadwick and Morrow 2011; Bell et al. 2013; Carballo et al. 2013; Loh et al. 2015; Chaves-Fonnegra et al. 2018). This is a cause for concern, as sponges are capable of outcompeting corals and other sessile reef organisms (Jackson and Buss 1975; Aerts 1999; Wulff 2012). Common means by which sponges outcompete corals include overgrowth, shading, smothering, and the use of allelochemicals (Porter and Targett 1988; Wulff 2006; Pawlik et al. 2007; Chadwick and Morrow 2011; Slattery and Gochfed 2012). 
Some sponges, such as those belonging to the genera Cliona and $A k a$, opportunistically colonize corals and use chemical and mechanical means to excavate the coral skeleton, resulting in direct mortality of coral tissue and bioerosion of the reef structure (Sullivan et al. 1983; Rützler 2002; ChavesFonnegra and Zea 2007; González-Rivero et al. 2016; de Bakker et al. 2018). The enhanced presence of sponges on reefs may affect not only the organisms currently on the reef, but also the ability of coral larvae to recruit and settle (Aronson et al. 2002; Vermeij 2006).

Sponges can both pre-empt space for coral recruits and competitively overgrow juvenile corals (Arnold and Steneck 2011; Luter et al. 2016). Indirect effects of sponges on coral recruitment may also result from interactions between sponges and other benthic competitors. For instance, research on sponge-macroalgae interactions has revealed complex and species-specific ecological associations that can influence space availability and, ultimately, coral cover (Trautman and Hinde 2001; Carballo and Ávila 2004; Easson et al. 2014). Nutrient exchange that occurs during direct contact between some species of sponge and macroalgae can suppress sponge competitive ability and promote macroalgal growth; this was demonstrated between Aplysina cauliformis and the macroalga Microdictyon marinum (Easson et al. 2014). Conversely, populations of other sponge species may be controlled by competitive superiority of macroalgae (López-Victoria et al. 2006; González-Rivero et al. 2016). The effect of one aggressive competitor can down-regulate the space pre-empting capability of another (Gonzalez-Rivero et al. 2016). If this down-regulation liberates space for recruitment of coral, for example, such interactions could indirectly benefit reef-building corals.

As Caribbean coral reefs continue to move away from coral-dominated states (Norström et al. 2009), it is important to understand factors influencing the potential for population growth or recovery of corals, particularly processes affecting recruitment (Ritson-Williams et al. 2009, Holbrook et al. 2018). Coral recruitment rates in some parts of the Caribbean have declined by an order of magnitude in recent decades (Vermeij 2006). A diversity of interacting biological and physical factors affect the recruitment of juvenile corals, and the numerous challenges that juvenile corals must overcome to reach adulthood has been referred to as "running the gauntlet" (Arnold et al. 2010). Environmental stressors, including reduced salinity, exposure to pollutants, elevated nutrients and sedimentation, can negatively affect settling corals or prevent their settlement altogether (reviewed in Ritson-Williams et al. 2009). Biological factors, such as the abundance of other benthic community members, can also influence coral settlement and post-settlement survival in both positive and negative ways (Edmunds et al. 2015). Macroalgal cover may prevent recruitment through space occupation or allelopathy (e.g., McCook et al. 2001; Kuffner et al. 2006; Birrell et al. 2005; Vermeij et al. 2009; Slattery and Gochfeld 2012; Morrow et al. 2017), whereas certain crustose coralline algae induce corals to settle (e.g., Morse et al. 1988; Arnold et al. 2010; Ritson-Williams et al. 2014, 2016). Likewise, as sponge cover increases, its relative impact on coral recruitment will likely increase.

Species-specific chemical signals likely play an important role in determining whether corals can settle on coral reef substrata (Ritson-Williams et al. 2009; Slattery and Gochfeld 2012). Corals inhibit the recruitment of heterospecific larval recruits by releasing chemicals that are harmless to conspecifics, but kill the swimming larvae and prevent the settlement of heterospecific scleractinian species in their vicinity (Chadwick and Morrow 2011). For example, the soft coral Sinularia flexibilis was shown to inhibit the recruitment of scleractinian coral spat on nearby substrata (Maida et al. 1995). Sponge chemical defenses can inhibit the growth of other sponges and tunicates (Engel and Pawlik 2000). They have also been demonstrated to affect the recruitment of other invertebrates (Bingham and Young 1991), and can potentially affect coral larvae and recruitment success (Chaves-Fonnegra, unpublished data). Similarly, decreased post-settlement coral survival has been linked to overgrowth by fast-growing sponges (Vermeij 2006; Arnold and Steneck 2011). Sponges replaced corals as the dominant benthic inhabitants on some Caribbean reefs after an El Niño event (Aronson et al. 2002), and their diverse secondary metabolites affect corals at various life-history stages (Pawlik 2011; Slattery and Gochfeld 2012). Chemical extracts from several species of Caribbean sponges have been found to reduce the chlorophyll $a$ concentrations and photosynthetic efficiency of zooxanthellae in adult colonies of Diploria labyrinthiformis (Pawlik et al. 2007), and both the sponge and exudate of Plakortis halichondrioides adversely affected photosynthetic activity and caused tissue necrosis in several species of Caribbean corals (Porter and Targett 1977). Juvenile corals are especially susceptible to competition because of their small size and high proportion of energetic resources allocated to growth (Vermeij 2006), and impacts of being in proximity to chemically defended sponges could be even greater to coral recruits than later life-history stages.

In the US Virgin Islands (USVI), shallow coral reefs have seen dramatic declines in coral cover due to combined impacts from local stressors, such as sediment input from land-based development (Nemeth and Nowlis 2001; Smith et al. 2008), and regional stressors, including temperaturedriven mass bleaching events (Smith et al. 2013). Space created by the loss of living coral has largely been occupied by macroalgae, but also by sponges (Smith et al. 2016). Recruitment of new corals to these reefs is critical to their recovery to coral-dominated states, but it may be prevented by the pre-emption of space by sponges and macroalgae, and the potential influence of their chemical defenses and/ 
or overgrowth capacity on coral recruitment. Within the USVI, coral recruitment was quantified in St. Croix in the early 1980s (Rogers et al. 1984) and more recently along the south coast of St. John (Green and Edmunds 2011). These studies found coral recruitment to vary with depth (Rogers et al. 1984) and temperature regime (Green and Edmunds 2011), and recruitment on St. John may be determined by overall water current patterns (Green and Edmunds 2011). To our knowledge, no study has quantified coral recruitment rates for St. Thomas, the second largest and most densely populated of the three islands in the USVI. In this study, we provide the first estimates of coral recruitment rates across a diversity of coral reef sites surrounding the island of St. Thomas and test the hypothesis that sponges negatively impact coral recruitment.

\section{Methods}

\section{Study sites}

In the USVI, multiple sites distributed across the territory have been annually monitored since 2001 by the Virgin Islands Territorial Coral Reef Monitoring Program (TCRMP) administered through the University of the Virgin Islands' Center for Marine and Environmental Studies (CMES) using standard benthic assessment techniques. These sites represent a range of habitat types and are located along a gradient of possible human induced stress, as indicated by terrigenous sediment deposition (Smith et al. 2008). Of the 33 territory-wide TCRMP sites, experiments in this study were completed at six shallow sites located around St. Thomas (Fig. 1, Table 1). Three sites (Black Point, Coculus Rock, Magen's Bay) were located in embayments with heavily developed watersheds (i.e., high human impact). Two sites (Savana Island, Buck Island) were located near undeveloped offshore cays

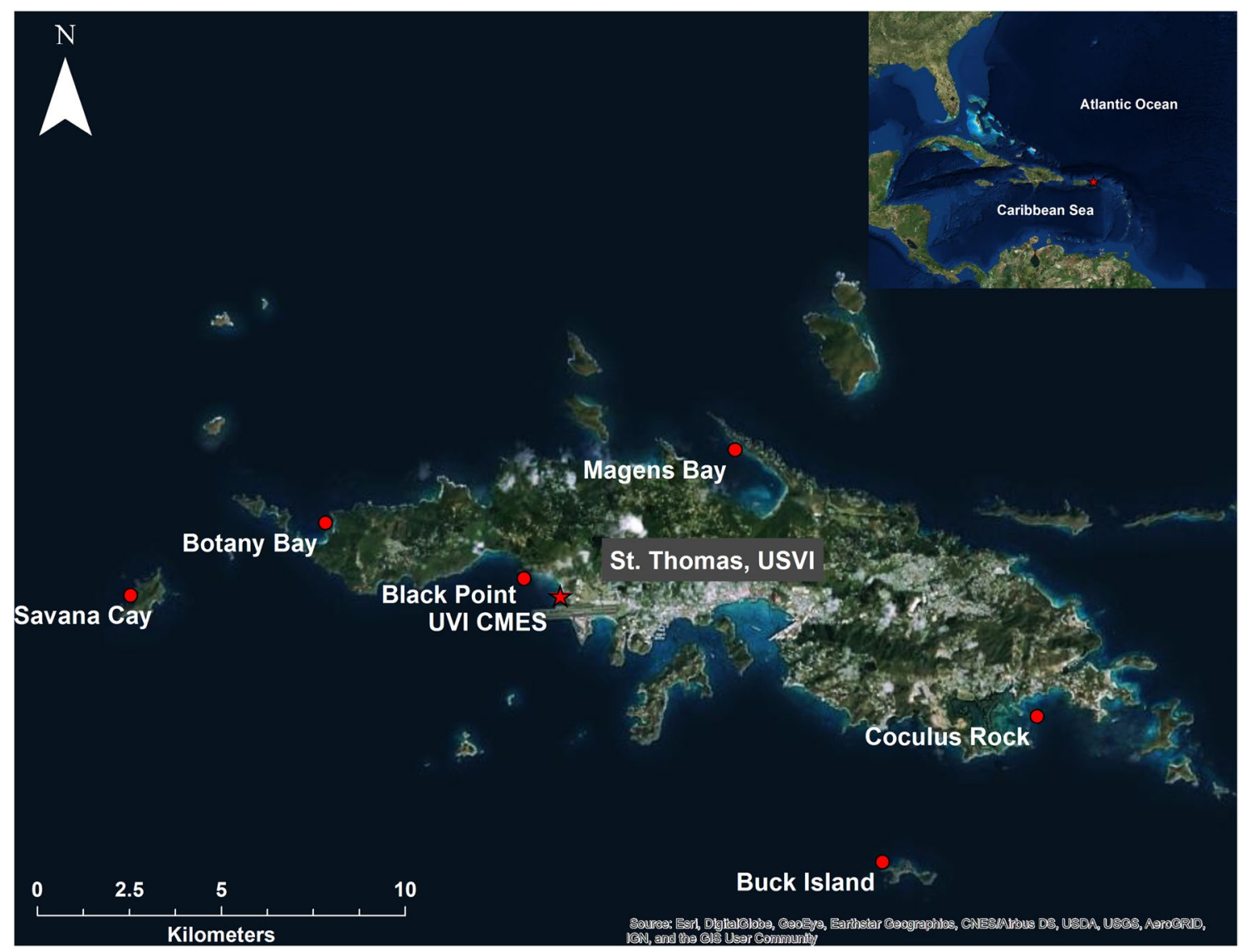

Fig. 1 Map of study sites around the island of St. Thomas, US Virgin Islands with World Imagery (Clarity) basemap. Location of the University of the Virgin Islands' Center for Marine and Environmental
Studies (UVI CMES) is indicated with a star. Inset: location of St. Thomas in the Caribbean Sea 
Table 1 Study sites on St. Thomas, including geographic coordinates, average depth of the study area, and average percent cover of hard corals and sponges $( \pm \mathrm{SE})$ as recorded by the Virgin Islands Territorial Coral Reef Monitoring Program in 2015 and 2016

\begin{tabular}{|c|c|c|c|c|c|c|c|}
\hline \multirow[t]{2}{*}{ Site } & \multirow[t]{2}{*}{ Latitude } & \multirow[t]{2}{*}{ Longitude } & \multirow[t]{2}{*}{ Depth (m) } & \multicolumn{2}{|c|}{ Hard \% Coral Cover } & \multicolumn{2}{|c|}{ Sponge $\%$ Cover } \\
\hline & & & & 2015 & 2016 & 2015 & 2016 \\
\hline Black Point (BP) & 18.34450 & -64.98595 & 9 & $18.4 \pm 2.3$ & $18.2 \pm 2.6$ & $11.0 \pm 0.7$ & $10.9 \pm 0.7$ \\
\hline Coculus Rock (CR) & 18.31257 & -64.86058 & 7 & $11.0 \pm 1.7$ & $13.0 \pm 0.9$ & $6.4 \pm 0.7$ & $5.7 \pm 0.8$ \\
\hline Magens Bay (MB) & 18.37425 & -64.93438 & 7 & $3.6 \pm 0.9$ & $4.1 \pm 0.9$ & $6.1 \pm 1.0$ & $5.5 \pm 1.3$ \\
\hline Botany Bay (BB) & 18.35845 & -65.03330 & 8 & $10.8 \pm 1.6$ & $8.8 \pm 1.1$ & $4.2 \pm 0.9$ & $4.2 \pm 1.2$ \\
\hline Buck Island (BI) & 18.27883 & -64.89833 & 14 & $6.8 \pm 0.6$ & $5.8 \pm 0.7$ & $6.5 \pm 1.0$ & $8.4 \pm 0.6$ \\
\hline Savana Island (SV) & 18.34064 & -5.08205 & 9 & $7.7 \pm 1.9$ & $7.3 \pm 1.6$ & $1.3 \pm 0.5$ & $1.2 \pm 0.6$ \\
\hline
\end{tabular}

(i.e., unimpacted), and one site (Botany Bay) was located in an embayment with a few large houses, which is in the process of being developed by a luxury housing project (i.e., low human impact).

\section{General approach}

There were three components to this study. Variability in coral recruitment among study sites was evaluated for comparison to the previous studies and to determine whether recruitment was related to the benthic structure of the reefs themselves. The other two components consisted of experiments that tested the impact of sponges on recruitment rates; Experiment 1 tested the speciesspecific effect of the common sponge, Aplysina cauliformis, on coral recruitment; and Experiment 2 tested the effect of the entire sponge community on coral recruitment rates. All experiments involved deploying terracotta recruitment tiles, but the Site-Specific Coral Recruitment Rate Assessment and Experiment 1 were conducted at all six sites, while Experiment 2 took place only at Black Point and Savana Island. Time frames and experimental conditions differed among components (Table 2).

\section{Site-specific coral recruitment rate assessment data collection: quantifying coral recruitment rates among the six study sites}

Coral recruitment rates were quantified at all six sites between 2016 and 2017 to compare recruitment rates across sites and to previously published rates. To accomplish this, ten blank tiles were randomly deployed at each site in two time periods: Period 3 (August 2016-March 2017) and Period 4 (March 2017-August 2017). Time periods for tile deployment were selected to represent the same durations and seasons studied by Green and Edmunds (2011), for comparison purposes.

In August 2016, recruitment tiles were deployed using a design modified from Mundy (2000) and Green and Edmunds (2011). Specifically, unglazed $15 \times 15 \times 1 \mathrm{~cm}$ terracotta tiles with a small hole drilled in the center were seasoned by placing them under the CMES dock for at least 1 month prior to deployment. At each site, ten seasoned tiles were affixed to dead coral substrate in random locations using stainless-steel lag screws. An approximate $1 \mathrm{~cm}$ gap was created using trimmed clear cable ties to allow settlement of coral recruits on the undersides of the tiles. Tiles were placed in random locations in the vicinity of permanent TCRMP transects at each site, and depths corresponded

Table 2 Summary of the design characteristics and time frame of the three study experiments

\begin{tabular}{|c|c|c|c|c|}
\hline Study component & Method & Tile or plot description & $N$ & Time frame \\
\hline $\begin{array}{l}\text { Site-specific coral recruitment rate } \\
\text { assessment. Testing the effect of } \\
\text { site on coral recruitment }\end{array}$ & Blank tiles & Blank & 10 & $\begin{array}{l}7 \text { months }(08 / 2016- \\
03 / 2017), \text { then } 5 \text { months } \\
(03 / 2017-08 / 2017)\end{array}$ \\
\hline \multirow{6}{*}{$\begin{array}{l}\text { Experiment } 1 . \text { Sponge species-spe- } \\
\text { cific effects. Testing the effect of } \\
\text { Aplysina cauliformis transplants } \\
\text { on coral recruitment }\end{array}$} & \multirow{3}{*}{$\begin{array}{l}\text { Tiles with sponge transplants on } \\
\text { top }\end{array}$} & Sponge on top & 8 & \multirow[t]{3}{*}{7 months $(08 / 2015-03 / 2016)$} \\
\hline & & Control with skeleton & 8 & \\
\hline & & Control blank & 4 & \\
\hline & \multirow{3}{*}{$\begin{array}{l}\text { Tiles with sponge transplants } \\
\text { around edges }\end{array}$} & Sponge on side & 8 & \multirow[t]{3}{*}{5 months $(03 / 2016-08 / 2016)$} \\
\hline & & Control with skeleton & 8 & \\
\hline & & Control blank & 4 & \\
\hline \multirow{2}{*}{$\begin{array}{l}\text { Experiment } 2 . \text { Sponge community- } \\
\text { level effects. Testing the effect of } \\
\text { sponge community removal on } \\
\text { coral recruitment }\end{array}$} & \multirow[t]{2}{*}{ Blank tiles within $1 \mathrm{~m}^{2}$ plots } & Plot with all sponges removed & 9 & \multirow{2}{*}{$\begin{array}{l}7 \text { months }(08 / 2015- \\
03 / 2016), \text { then } 5 \text { months } \\
(03 / 2016-08 / 2016)\end{array}$} \\
\hline & & $\begin{array}{l}\text { Plot with no sponges removed } \\
\text { (control) }\end{array}$ & 9 & \\
\hline
\end{tabular}


to $\pm 2 \mathrm{~m}$ from those listed for each site in Table 1 . Tiles were located at least $1 \mathrm{~m}$ away from transect lines so as not to interfere with long-term monitoring. Numbered aluminum tags were hammered into dead substrate near each tile. Upon deployment, reference photographs of the tags and tiles were taken.

All tiles were collected from study sites in March 2017. Tiles were unscrewed from the reef and placed into individual resealable plastic bags with their numbered tags. Pre-seasoned replacement tiles for Period 3 were then screwed into the same holes and marked with new numbered aluminum tags. All tiles from Period 4 were collected in August 2017 as described for the completion of Period 3.

\section{Experiment 1: testing the effect of sponge transplants on coral recruitment (sponge species-specific effects)}

To test the effect of proximity to a common sponge on coral recruitment, recruitment tiles were deployed as described above, but with and without sponge and sponge control treatments. At each site, 8 treatment tiles, 8 control tiles, and 4 blank tiles (no sponges) were deployed during two time periods: Period 1 (August 2015 to March 2016) and Period 2 (March 2016 to August 2016). The sponge and sponge control treatments consisted of living or skeletal (non-living) fragments of Aplysina cauliformis. This species of sponge was selected for testing due to its diversity of chemical defenses (Gochfeld et al. 2012), as well as its high abundance and prevalence of interactions with corals on St. Thomas' reefs (Gochfeld and Olson, unpublished data).
For Period 1, treatment tiles had a living $10 \mathrm{~cm}$ length fragment of A. cauliformis attached to the center of the tile using cable ties (Fig. 2a). Fragments of A. cauliformis were collected using shears from sponges found at each site and were transplanted onto the recruitment tiles immediately after collection. Control tiles consisted of similarly attached $10 \mathrm{~cm}$ fragments of $A$. cauliformis skeleton. The skeletons were created by soaking living pieces of $A$. cauliformis collected from the same reefs in a $10 \%$ bleach solution to kill the sponge, followed by rinsing the pieces in freshwater for $48 \mathrm{~h}$, and drying them in the sun for 3-4 days. Blank tiles (with no sponge) were deployed in an identical manner. Tiles were visited approximately monthly to check on the condition of the attached sponge fragments and to replace the sponge or sponge skeleton fragments when necessary. Replacements were rare; only 1-2 living or dead pieces of sponges were replaced at each site over the course of the study.

All tiles from Period 1 were collected from study sites in March 2016 as described for the Site-Specific Coral Recruitment Rate Assessment and replaced with pre-seasoned tiles. Again, sample sizes consisted of 8 treatment tiles, 8 control tiles, and 4 blank tiles. However, for the second tile deployment, the sponge treatment was applied such that living sponge surrounded the entire perimeter of the tile (Fig. 2b). On control tiles, the sponge skeletons were attached in an identical manner around the tiles' perimeters. All tiles from Period 2 were collected in August 2016.

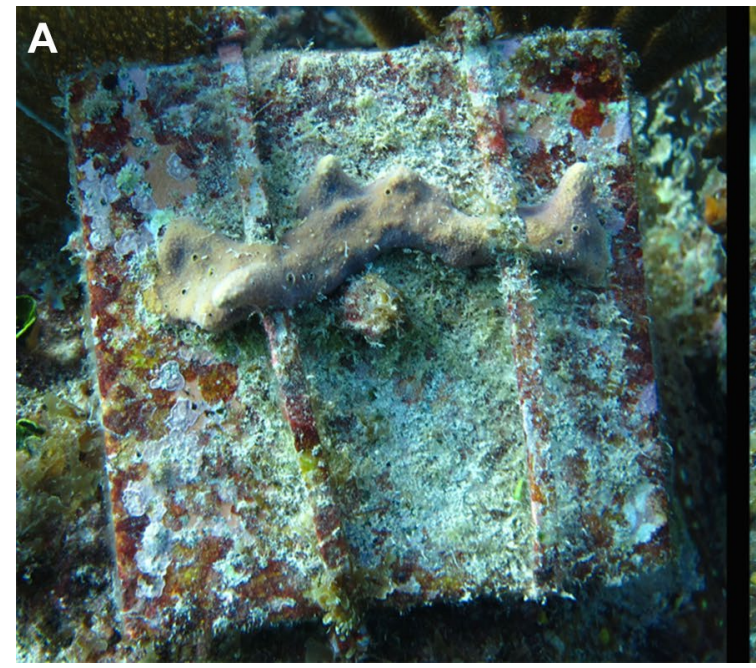

Fig. 2 a Recruitment tile in Period 1 with a $10 \mathrm{~cm}$ Aplysina cauliformis transplant on top of the tile, photographed 5 months after deployment. The A. cauliformis fragment overgrew its cable ties and continued growing after it was transplanted onto the tile. b Recruit-

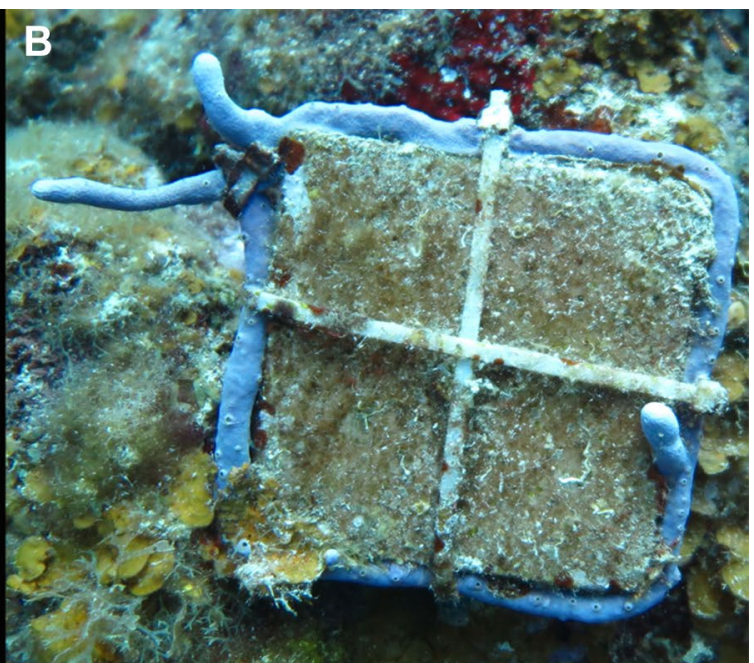

ment tile in Period 2 with A. cauliformis transplants attached to the perimeter of the tile. The A. cauliformis attached to the tile and continued growing 


\section{Experiment 2: testing the effect of sponge community removal on coral recruitment (sponge community-level effects)}

In August 2015, triplicate $1 \mathrm{~m}^{2}$ plots were marked and manually cleared of sponges at Black Point (a nearshore site) and Savana Island (an offshore site) by hand and with the use of scissors and/or metal scrapers. Although organisms growing directly on the sponges themselves, such as macroalgae, were also removed in the process of removing the sponges, efforts were made not to disturb the macroalgae or other benthic organisms otherwise. All sponges from the cleared experimental plots were collected into plastic bags and the displacement volume and wet and dry weight of the sponges were measured in the laboratory. Triplicate uncleared (control) plots were also marked at these sites. Within each marked plot, three seasoned recruitment tiles were deployed, for a total of 18 tiles per site, with 9 tiles per treatment (cleared, uncleared control). Tiles were collected and replaced with new tiles in March 2016 and were processed in an identical manner to those deployed in the sponge transplant experiment. Replacement tiles were then collected and processed in August 2016. At that time, all six plots at each site (i.e., previously cleared and control plots) were cleared of all sponges, and displacement volume and weights of cleared sponges from each plot were measured in the laboratory.

\section{Tile processing}

For all experiments in all time periods, bagged tiles were placed inside coolers with seawater immediately after collection and transported by boat to CMES, where tiles were removed from the bags and placed in a running seawater table until processed ( $24 \mathrm{~h}-2$ weeks). Processing consisted of photographing both sides of the plates with a Canon G12 camera, followed by observing both sides of each plate under a Lecia S6D dissecting microscope to count all coral recruits. Phylogenetic identification of recruits was difficult, since the majority were single corallites with skeletal features that were not completely formed; thus, results are presented as all coral recruits combined. Reference photographs of coral recruits were taken with a Nikon DS-fil microscope camera for comparison with bryozoans to prevent misclassification. Reference photographs of confirmed coral recruits were reviewed for genus and species identification by Dr. Raphael Ritson-Williams.

\section{Data analysis}

\section{Calculation of coral recruitment rates}

Coral recruitment rates were calculated as a daily rate per unit area: as the number of recruits on a tile divided by the number of days that the tile was deployed on the reef, and then scaled up to $1 \mathrm{~m}^{2}$. Some deployed tiles were lost, probably due to wave action. Therefore, sample sizes were not equal across all the treatments, sites, and time periods (Suppl Table A).

\section{Analysis of site-specific coral recruitment rate data}

Recruitment rate data for Periods 3 and 4 were fourth-roottransformed to meet the assumptions of normality and homogeneity of variance before applying a two-way Analysis of Variance (ANOVA) to test for the effects of time, period, and site. Post hoc, pair-wise comparisons were performed using Tukey's Honestly Significant Difference (HSD) test. To determine if coral recruitment patterns across sites were a function of any component of the benthic community structure at the sites, separate multiple regression analyses were applied to recruitment rate data from each time period. Average coral recruitment rates at sites in Periods 3 and 4 were tested separately as the response variable, while predictor variables in each analysis included site-specific average percent cover of living hard coral, sponges, macroalgae, and the epilithic algal community (EAC: i.e., diminutive turf algae and other low complexity filamentous algal communities). These percent cover data were recorded at the study sites in 2016 by the TCRMP (Suppl Table B). The benthic categories used as predictors in the multiple regression models composed greater than $88 \%$ of living cover at all the sites.

\section{Analysis of experiment 1 (sponge transplants on recruitment tiles)}

Data for Periods 1 and 2 were analyzed separately due to the differences in sponge fragment orientation on the tiles. For each time period, a two-way ANOVA was applied to square-root transformed recruitment rates; treatment type (i.e., living sponge, skeleton, blank) and site were tested as main effects in the model. Post hoc, pair-wise comparisons were performed using Tukey's HSD test.

\section{Analysis of experiment 2 (coral recruitment in cleared versus uncleared plots)}

Displacement volumes and dry weights of removed sponges were each analyzed using a two-way ANOVA with site and time period/treatment level (i.e., cleared-initial, clearedfinal, uncleared control-final), as the two main effects. Wet weights were also compared, but followed a nearly identical pattern to dry weights and so are not presented. Displacement volume data were square-root-transformed and dry weight data were fourth-root-transformed to meet the assumptions of ANOVA. 
Data from recruitment tiles in cleared and uncleared control plots were zero inflated and did not conform to assumptions of parametric tests, even with transformation. Therefore, these data were analyzed using a generalized linear model (GLM), applying a Poisson distribution and log link function (i.e., a three-way contingency table with log-linear analysis). The GLM tested for the effects of time period (Period 1, Period 2), site (Black Point, Savana Island), and plot type (cleared, uncleared) on the frequencies of coral recruits recorded on the plates. Potential nesting effects of tiles within plots were first tested and found to be not significant; therefore, plot was not included as a nested effect in the GLM. All analyses were performed in JMP v. 12 (SAS Inc.).

\section{Results}

When all tiles $(n=418)$ were considered, regardless of treatment or time period, we calculated an average recruitment rate of $0.21 \pm 0.02$ (SE) recruits day ${ }^{-1} \mathrm{~m}^{-2}$. Of the 347 recruits found, all but one was found on the bottom sides of the recruitment tiles. Overall, recruitment rates were greatest in Period 1, followed by Periods 4, 2, and 3 (Suppl Table C). Reference photographs for 85 of the recruits were examined, and of these, 45 recruits (53\%) could be identified to genus, while the rest were too small to be confidently identified. All 45 identifiable recruits were identified as Agaricia spp.

\section{Site-specific coral recruitment rates}

Recruitment rates on blank tiles in Periods 3 and 4 were comparable to rates recorded during experiments in Periods 1 and 2. Recruitment rates did not differ between Periods 3 and $4(F=3.12, P=0.0797)$, but there was a significant effect of site $(F=7.89, P<0.0001)$. Black Point had the highest recruitment rates, but they were not significantly different from Coculus Rock or Buck Island (Fig. 3). Magens Bay, Botany Bay, and Savana Island all had significantly lower rates of recruitment than Black Point, and Botany Bay also had significantly lower rates of coral recruitment when compared with Coculus Rock and Buck Island (Fig. 3). No interaction was recorded between site and time period $(F=1.58, P=0.17)$. The multiple regression analyses showed no relationship between any of the benthic categories tested and average recruitment rates recorded in Period $3(F=16.7460, P=0.1810)$ or Period $4(F=1.2572$, $P=0.5771)$. These data also confirmed the consistently low recruitment rates observed in Experiments 1 and 2.

\section{Experiment 1: the effect of sponge transplants on coral recruitment}

In Period 1, recruitment on tiles varied significantly across sites, but there was no effect of sponge treatment or any

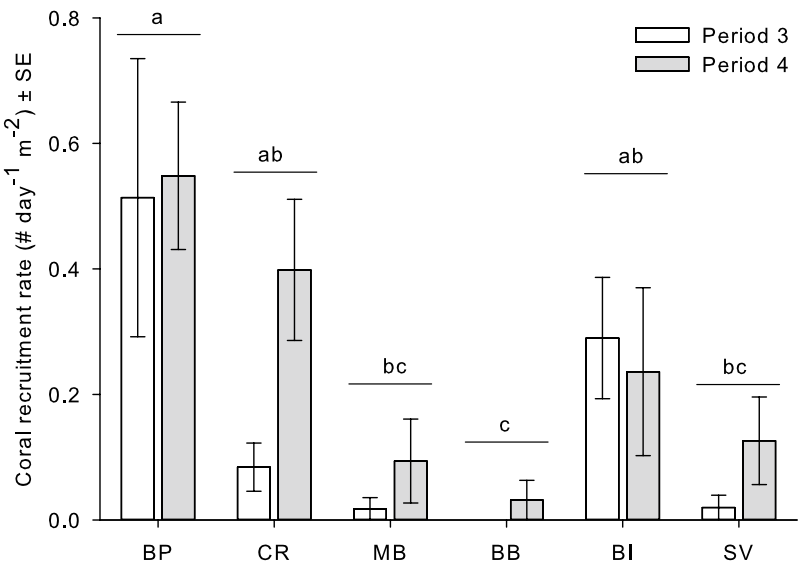

Fig. 3 Mean recruitment rates (\# recruits day ${ }^{-1} \mathrm{~m}^{-2} \pm$ SEM) recorded on blank tiles ( $n=10 /$ site) across six sites for Period 3 (August 2016March 2017) and Period 4 (March-August 2017). Letters indicate significant differences among sites, as determined by post hoc Tukey's HSD pair-wise comparisons where $P<0.05$. Where bars are not apparent (i.e., BB-Period 3), there was no recruitment recorded on the plates

interaction between site and treatment (Table 3). Coral settlement was significantly higher at Black Point than at any other site, and significantly higher at Coculus Rock compared to Botany Bay and Savana Island (Fig. 4a). In Period 2, the ANOVA revealed similar patterns (Table 3), and recruitment was again significantly higher at Black Point compared to all sites except Savana Island (Fig. 4b).

\section{Experiment 2: the effect of sponge community removal on coral recruitment}

For plots that were cleared in 2015 , there was virtually no sponge recovery or recruitment by the time those same plots were re-cleared in 2016 (Fig. 5). Dry weights of sponges cleared from experimental plots in August 2015 and the same plots in August 2016, as well as from control plots in August 2016 were significantly different between treatment/ time periods $(F=61.7654, P<0.0001)$, with dry weights being similarly high in the initial experimental plots and in control plots cleared for the first time in August 2016, relative to dry weights of sponges from experimental plots that were re-cleared in August 2016 (Fig. 5a). While there was a significant interaction between site and treatment/ time period $(F=1.406, P=0.043)$, post hoc pair-wise tests could not differentiate groups beyond the differences observed among treatment/time periods, and there was no significant effect of site $(F=0.0023, P=0.9625)$. However, displacement volumes of sponges were significantly different between sites $(F=7.0012, P<0.05)$ and treatment/ time periods $(F=1810.99, P<0.0001)$, and there was a significant interaction between site and treatment/time period 
Table 3 Statistical results of two-way ANOVA tests for effect of site and Aplysina cauliformis treatment (living sponge, skeleton, and blank) on coral recruitment rates

\begin{tabular}{llrrr}
\hline Time Period & Source & DF & F & P \\
\hline Period 1 (Aug 2015-March 2016) & Site & $\mathbf{5}$ & $\mathbf{1 6 . 5 2 1 2}$ & $<\mathbf{0 . 0 0 0 1}$ \\
& Treatment & 2 & 0.2186 & 0.8040 \\
& Site $\times$ treatment & 10 & 0.3188 & 0.9744 \\
Period 2 (March 2016-Aug 2016) & Site & $\mathbf{5}$ & $\mathbf{5 . 4 3 6 6}$ & $<\mathbf{0 . 0 0 1}$ \\
& Treatment & 2 & 0.3061 & 0.7370 \\
& Site * treatment & 10 & 1.1366 & 0.3425 \\
\hline
\end{tabular}

Bold indicates a significant effect $P<0.05$

$D F$ degrees of freedom, $F F$ statistic, $P P$ value
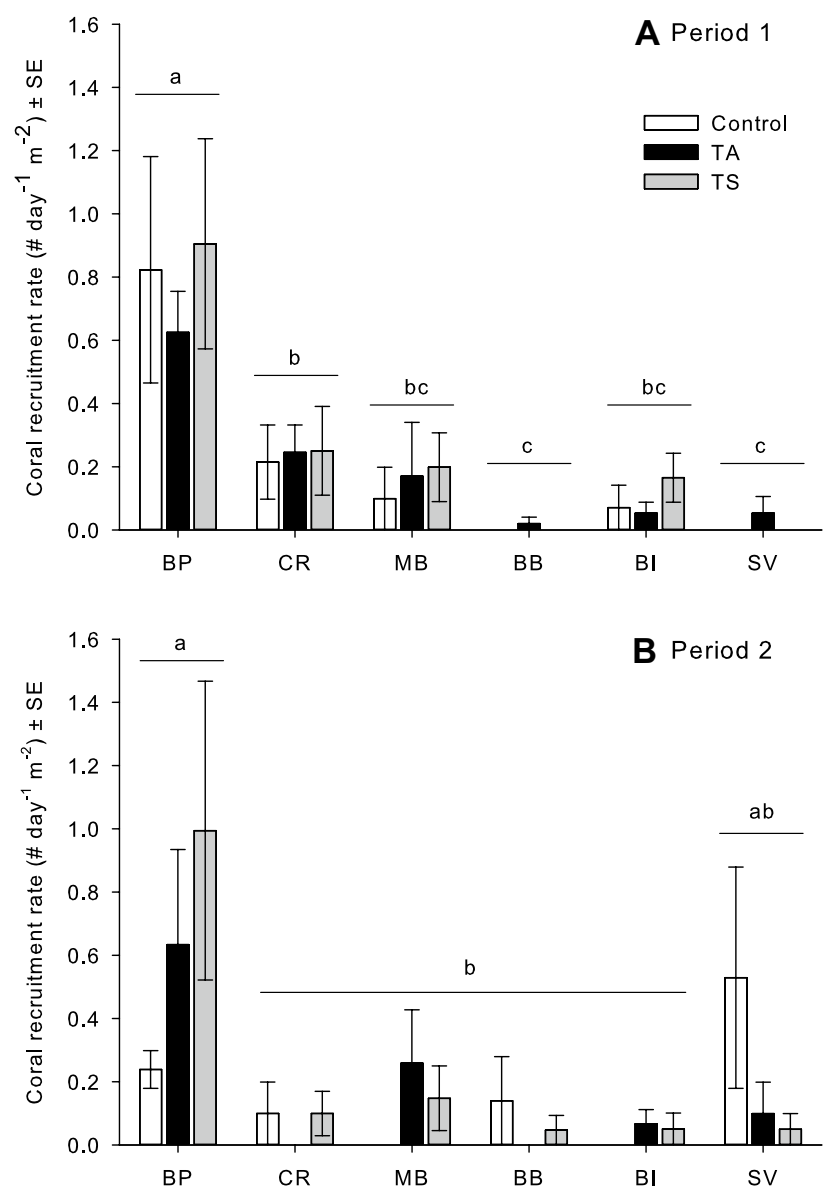

Fig. 4 Coral recruitment rates (\# recruits day ${ }^{-1} \mathrm{~m}^{-2} \pm \mathrm{SE}$ ) recorded on tiles that were blank (Control: $n=4)$, had a living fragment of Aplysina cauliformis attached (TA: $n=8$ ), or had a skeleton of $A$. cauliformis attached (TS: $n=8$ ) for a period 1 (August 2015-March 2016), and b period 2 (March-August 2016). Letters indicate significant differences across groups as determined by post hoc Tukey's HSD pair-wise comparisons where $P<0.05$. Where bars are not apparent (i.e., Period 1: BB-Control, BB-TS, SV-Control, SV-TS), there was no recruitment recorded on the plates. Site acronyms in Table 1

$(F=121.66, P<0.05)$. Displacement volume of sponges was the highest in experimental plots at Black Point when they were initially cleared in 2015 , followed by cleared experimental plots at Savana in 2015 and control plots cleared for the first time at both sites in 2016 (Fig. 5b). Like sponge dry weights, displacement volumes of sponges were significantly lower in the experimental plots when they were re-cleared in 2016 (Fig. 5b). Sponge communities within treatment and control plots were similar at each site (Suppl Table D).

Coral recruitment rates differed significantly between sites, and between cleared and control plots (Table 4). Coral recruitment was again highest at Black Point and was higher in plots where sponges were removed, as compared to control plots (Fig. 6).

\section{Discussion}

The coral recruitment rates recorded in this study were lower than those previously reported in the USVI, but rates were consistent across the four time periods tested (Suppl Table C). Our coral recruitment rates (overall: $0.21 \mathrm{~m}^{-2}$ per day) were around half as high as rates recorded by Green and Edmunds (2011) for St. John (76 corals $\mathrm{m}^{-2} 6$ months $^{-1}$, or $\sim 0.42 \mathrm{~m}^{-2}$ per day), but close to those recorded by Rogers et al. (1984) for St. Croix ( 23 corals $^{-2} 3$ months $^{-1}$, or $\sim 0.26 \mathrm{~m}^{-2}$ per day). Lower recruitment rates compared with historical studies may not be surprising in light of the observation that Caribbean coral recruitment rates have been declining over the last several decades (Vermeij 2006). Reductions in adult coral populations have likely contributed to declines in coral larvae. However, the Green and Edmunds (2011) study took place less than 10 years before this study, and no large reduction in coral cover occurred between these studies (Smith et al. 2016). More likely, physical and biological processes related to the sites themselves are responsible for the differences observed in recruitment rates among studies. Green and Edmunds (2011) observed declining recruitment along an east-to-west gradient on the south coast of St. John that could not be explained by the distribution of adult colonies. They instead suggested that this directional trend might be explained by the patch depletion/downstream filtering hypothesis that predicted the distribution of the bluehead 


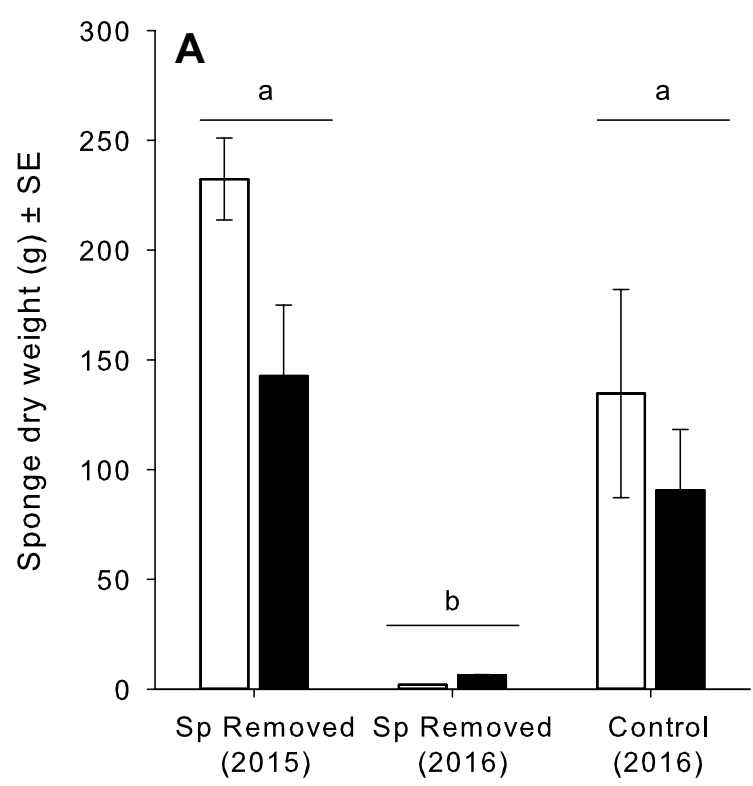

Fig. 5 Average ( \pm SE) dry weight (a) and displacement volume (b) of all sponges collected from three $1-\mathrm{m}^{2}$ plots at Black Point and Savana Island in August 2015 (Sp Removed 2015) and from those same plots in August 2016 (Sp Removed 2016), as well as from three control

Table 4 Statistical results of generalized linear model for effect of time period, site, and sponge community removal treatment (cleared, uncleared) on frequencies of coral recruits recorded on tiles

\begin{tabular}{lccc}
\hline Source & DF & L-R Chi-square & $P$ \\
\hline Time period & 1 & $1.6391 \mathrm{e}-8$ & 0.9999 \\
Site & $\mathbf{1}$ & $\mathbf{2 5 . 5 7 5 8 0 1}$ & $<\mathbf{0 . 0 0 0 1}$ \\
Time period $\times$ site & 1 & $6.9965 \mathrm{e}-7$ & 0.9993 \\
Treatment & $\mathbf{1}$ & $\mathbf{4 . 3 2 6 6 4 0 7}$ & $\mathbf{< 0 . 0 5}$ \\
Time period $\times$ treatment & 1 & $1.7892 \mathrm{e}-7$ & 0.9997 \\
Site $\times$ treatment & 1 & 2.0672221 & 0.1505 \\
Time period $\times$ site $\times$ treatment & 1 & $5.4417 \mathrm{e}-7$ & 0.9994 \\
\hline
\end{tabular}

Bold indicates a significant effect $P<0.05$

$D F$ degrees of freedom, $L-R$ Chi-square Likelihood Ratio Chi-Square statistic, $P P$ value

wrasse (Thalassoma bifasciatum) along the south shore of St. Croix (Caselle and Warner 1996). This hypothesis suggests that an aggregate of larvae is transported along the coast by water currents and is progressively depleted by recruitment of larvae to the benthos. This hypothesis relies on an upstream supply of larvae. Sites tested in our study were located around St. Thomas, which lies to the west of St. John, and were, therefore, even further downstream from the St. John sites used in Green and Edmunds (2011). If patch depletion/downstream filtering dynamics are in fact driving recruitment patterns, particularly in an east-to-west direction, and if local reproduction was very low, St. Thomas sites would be expected to experience lower recruitment rates

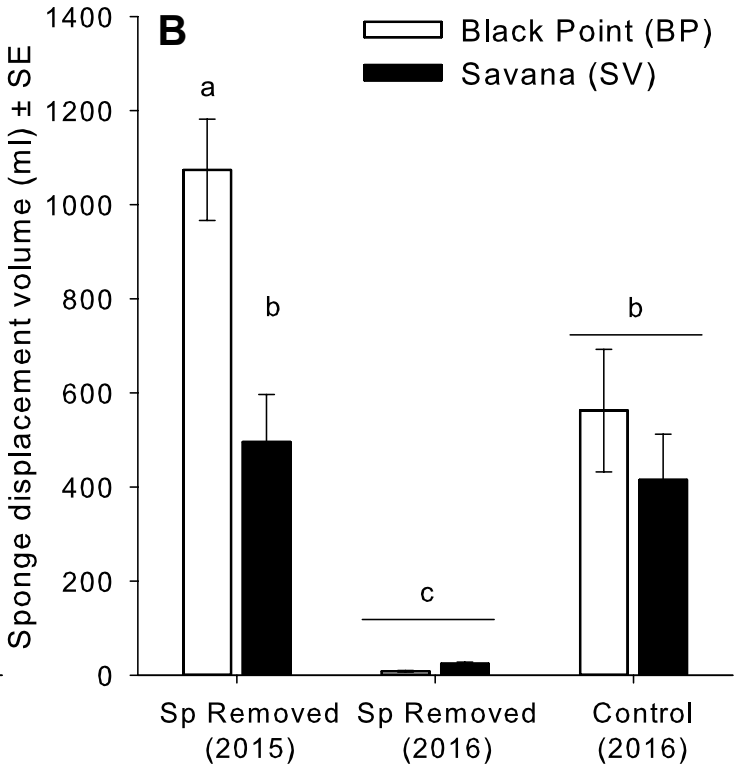

$1-\mathrm{m}^{2}$ plots from which sponges were removed for the first time in August 2016 (Control 2016). Letters indicate significant differences where $P<0.05$, as determined by Tukey's HSD pair-wise comparisons

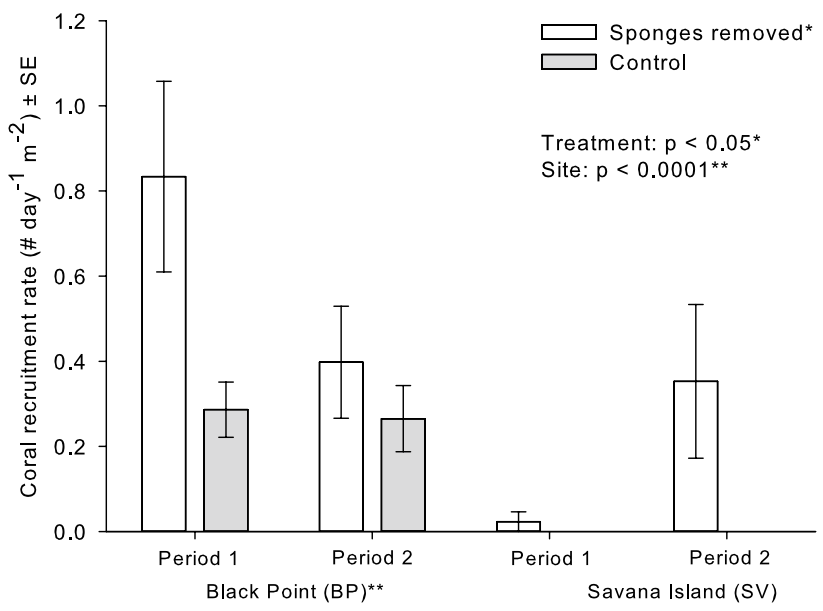

Fig. 6 Coral recruitment rates (\# recruits day ${ }^{-1} \mathrm{~m}^{-2} \pm \mathrm{SEM}$ ) within plots where sponges were removed and uncleared control plots at Black Point and Savana Island during Period 1 (August 2015-March 2016) and Period 2 (March-August 2016). Where bars are not apparent (i.e., SV-Period 1-Control, SV-Period 2-Control), there was no coral recruitment recorded on the plates. Results from the Generalized Linear Model indicated significant effects of Site $(* *)$ and Treatment (*) on coral recruitment rates. No effect of period or any significant interactions among independent variables were detected

than the lowest encountered on St. John reefs. However, in this study, we found that the majority of identifiable recruits were of the genus Agaricia, which consists of brooders (Gleason and Hofmann 2011) that spawn year-round (Urvoix et al. 2013, Arnold et al. 2010). Reproduction by brooding, 
where sperm is released and fertilization occurs internally, is known to lead to local retention of larvae in general (Gleason and Hofmann 2011). Therefore, local reproduction was likely the primary driver of site-specific recruitment patterns observed in this study.

Empirical studies on coral recruitment can be difficult to compare, because the type and preparation of recruitment plates greatly affects what will settle on them. A variety of materials have been used for recruitment plates (e.g., terracotta, glass, plexiglass, and coral skeleton), but terracotta tiles are most common and appear to attract the most recruits (Urvoix et al. 2013). Recruitment predominantly occurs on the cryptic underside of smooth tiles; this pattern has raised concern about how well this structure reflects natural reef substrate. Some contend that the low rugosity, and, therefore, greater exposure, on the artificial and smooth upperfacing tile surface may preclude recruitment, while others defend the use of tiles, maintaining that it is important to use a substrate with uniform architecture and minimal topographic variation (Arnold et al. 2010). Still others have attempted to simulate rugose microhabitats by wrapping tiles in wire mesh (Vermeij 2006). Unfortunately, the use of different settlement substrates can lead to varying taxonomic composition of recruits (Edmunds et al. 2014), and makes it difficult to draw global conclusions from studies incorporating only one type of experimental settlement substrate. The time and depth at which plates are pre-conditioned can also affect the type of bacterial biofilms and associated chemical cues that signal larval settlement (Webster et al. 2004). Inconsistent preparation of recruitment tiles may introduce further bias and hinder comparisons between experiments, even if conducted in the same location. To compare recruitment rates from our study with those reported by Green and Edmunds (2011), we followed their methods as closely as possible, and installed all tiles with the smooth side facing upwards. Like that previous study, we also found nearly all of the recruits to occur on the undersides of the plates. Although we attempted to maintain consistency between our study and previous studies in the region, the factors listed above may have played a role in differences detected in recruit abundance among studies.

In this study, coral recruitment was found to vary significantly among sites around St. Thomas, although the differences did not appear to be associated with human influence. For example, Black Point was located close to shore and considered to be heavily impacted by human activities, yet had the highest rates of recruitment recorded, whereas recruitment was lower and more temporally variable at the other five sites. Black Point also had the highest percent coral cover of all sites studied (Table 1), which may be indicative of favorable conditions for corals and possibly coral settlement, although no specific relationship between coral recruitment and coral cover was found in this study.
Despite this, the high coral cover at Black Point may provide a crucial source of propagules for recruitment. Black Point is also located in a more enclosed embayment than the other sites. A study by Sabine et al. (2015) found that clod card dissolution (as a proxy for water motion) was much lower at a site near Black Point, as compared to offshore sites and another nearshore reef site. Therefore, low water motion at Black Point may contribute to greater retention of coral larvae. The fact that all identifiable recruits were from brooding Agaricia spp. also suggests that the patterns of recruitment were driven by local site-scale dynamics. No other strong geographical patterns were found, although sites with the highest levels of recruitment tended to be located on the south side of the island. The north side of St. Thomas experiences seasonal swell during the winter months, which may impact the retention and settlement of coral larvae.

The attachment of living or dead fragments of the common sponge Aplysina cauliformis to the recruitment tiles had no effect on coral recruitment in this study. Aplysina cauliformis produces a diversity of secondary metabolites that defend the sponge from pathogens and predators (Gochfeld et al. 2012), although impacts of these compounds on any life-history stage of corals have not been tested previously. The absence of an effect in this study suggests that A. cauliformis is not detrimental to coral recruits, at least not at the scales that we tested. It is important to note that the vast majority of coral settlement occurred on the undersides of the recruitment tiles, while the experimental fragments of living and dead sponge were attached to the tops or edges of the tiles. Attachment of the sponge fragments to the undersides of the recruitment tiles, where coral recruitment typically occurred, would have prevented light from reaching the sponges. As A. cauliformis relies on photosynthetic cyanobacterial symbionts to supply a large portion of its energetic needs (Freeman and Thacker 2011), the sponge fragments likely would not have survived extended periods in that position. However, allelopathic effects of sponges on coral larval settlement or recruitment may only occur over very small distances if defensive secondary metabolites cannot diffuse into the water column or be exuded across any great distance. Whereas some sponges (e.g., Plakortis halichondroides) produce chemical defenses that can kill corals (e.g., Agaricia lamarcki) upon direct or indirect contact via waterborne metabolites (Porter and Targett 1988), whether A. cauliformis possesses similar defenses remains to be seen.

In the cleared plots, where all sponges were removed from the area of recruitment tiles, there was a significant positive effect on recruitment. This suggests that some aspect or aspects of the entire sponge community negatively affects coral recruitment. Recent studies have highlighted complexities in coral larval behavior (Gleason and Hofmann 2011). To settle on a reef, larvae must become competent and develop a capacity to swim towards a reef substratum. 
A number of chemical cues are responsible for instigating the transition to competency and subsequent settlement (Ritson-Williams et al. 2009). The "smell" of the sponge-free plots may have been different and more inviting to the coral larvae compared with the uncleared plots. Some sponges produce secondary metabolites that encourage the settlement of invertebrate larvae (Bingham and Young 1991), whereas others have antifouling and allelopathic chemical defenses (Qian and Xu 2012; Slattery and Gochfeld 2012) that could deter larval settlement, or could generate an inhospitable substratum for coral recruits if they settled on top of or close to sponges. Some sponge compounds may attract larvae, but inhibit subsequent metamorphosis (Green et al. 2002). Sponge presence may also affect small-scale flow movements, for example, by increasing turbulence, which could impact the settlement ability of coral larvae (Bingham and Young 1991). Alternatively, coral recruits may have inadvertently been preyed upon by spongivores feeding in the area of the plots; however, spongivores make up only $6 \%$ of the fish community at Black Point and less than $1 \%$ of the community at Savana (Smith et al. 2016). These potential mechanisms by which sponge communities might inhibit coral recruitment represent important areas for future research.

An interesting aspect of our study was the slow recovery of sponges within the cleared plots. Sponge removal in the cleared plots was very thorough, involving removal by hand, scraper, and, finally, metal brushes. Thus, the substrate of cleared plots was abraded, which might have changed the texture of the substratum or eliminated other epifauna that could attract sponge larvae (Sutherland and Karlson 1977; Zea 1993). Therefore, sponge recruitment in cleared plots may have been restricted by the presence of suitable surfaces for larval attachment. In addition, overgrowth of cleared surfaces by algae could prevent sponge larvae from successfully recruiting into those areas, as sponge larvae have been shown to prefer to recruit to established biofilms on solid substrates (Whalan and Webster 2014). Any remaining sponge fragments would have been very small, and while some tissue regeneration could have occurred, it might have been further damaged by grazing fishes, although the abundance of spongivores is low at Black Point and they are nearly absent from Savana (Smith et al. 2016).

Although we were not able to definitively discern phylogenetic differences for a large portion of our recruits, results from those we could identify were consistent with other studies that reported the majority of recruits observed on recruitment plates in the Caribbean were members of the brooding genera Agaricia and Porites (Urvoix et al. 2013; Arnold et al. 2010). Green and Edmunds (2011) found that recruitment in St. John was also dominated by agaricids and poritids, but a considerable amount of faviids and siderastreids were also found (17\% and 7\%, respectively).
The brooding species Agaricia agaricites is the most abundant recruit on many Caribbean reefs; $A$. agaricites grows quickly and can withstand sedimentation, but is less capable of wound repair and is frequently outcompeted (Ritson-Williams et al. 2009). However, the coral species that comprise a majority of the framework of most Caribbean reefs-namely the faviids Orbicella spp.—are broadcast spawners. These species have tremendously low recruitment rates, mature to adulthood slowly, and are threatened by the Allee effect at low population densities (Ritson-Williams et al. 2009; Darling et al. 2012). The higher rates of recruitment and relatively large proportion of faviids present within the St. John recruit community documented by Green and Edmunds (2011) could indicate more favorable conditions for recruitment on those reefs compared with the reefs of St. Thomas. However, our study and that of Green and Edmunds (2011) did not overlap temporally, and it is possible that the timeframe of Green and Edmunds (2011) corresponded with a time of favorable conditions for broadcast spawners. In general, the lack of recruitment of broadcast spawning species in our study and others may imply future reef conditions dominated by weedier, brooding species, and a subsequent loss or reduction of reef framework in the Caribbean.

Coral recruitment represents a primary mechanism for coral recovery (Edmunds et al. 2015; Holbrook et al. 2018). There is a distinct need to better understand the dynamics of coral recruitment, especially on Caribbean reefs where coral cover has been consistently declining. Future avenues of research should include determining how sub-lethal stress brought on by space competitors, such as sponges and algae, may influence both settlement and post-settlement coral health and survivorship. Emphasis should also be placed on evaluating how other organisms (e.g., sponges) influence nearby recruitment patterns. Finally, top-down controls, such as abundance of grazing fishes, should continue to be evaluated in relation to recruitment density. A thorough comprehension of recruitment dynamics will lead to a better understanding of reef resilience and help inform the most effective strategies to manage deteriorating Caribbean reef ecosystems.

Acknowledgements We thank E. Brown, A. Gutting, J. Ruggiero, T. Rabsatt, L. Williams, J. Keller, V. Beasley, R. Brewer, E. Kadison, R. Ennis, D. Lasseigne, and R. Sjoken for assistance with field work. We thank T. B. Smith, R. Ennis, and the Territorial Coral Reef Monitoring Program for providing project support and benthic cover data, and R. Ritson-Williams for identifying our coral recruits from photographs. We also thank P. Jobsis, S. Prosterman, I. Byrne, R. Tonge, and G. Gonsalves for logistical support, and V. Brandtneris and D. Lasseigne for assistance with manuscript figure preparation. M. Brandt would like to thank the Tougaloo College ADVANCE summer writing retreat program.

Funding Funding for the work was provided by a NOAA Coral Reef Conservation Program grant (\#NA15NOS4820074) to M. Brandt, D. 
Gochfeld, and J. Olson and by VI EPSCoR (NSF \#0814417). This work was also supported in part by the National Science Foundation (under grant HRD-1463991). Any opinions, findings, and conclusions or recommendations are those of the authors and do not necessarily reflect the views of NSF. This is contribution \#194 from the University of the Virgin Islands' Center for Marine and Environmental Studies.

\section{Compliance with ethical standards}

Conflict of interest All authors declare that they have no conflict of interest.

Human or animal rights Research was conducted under the Virgin Islands Department of Planning and Natural Resources (VI DPNR) permit \#DFW15050T and DFW15085T. All national and institutional guidelines for the use of animals were followed.

Open Access This article is distributed under the terms of the Creative Commons Attribution 4.0 International License (http://creativeco mmons.org/licenses/by/4.0/), which permits unrestricted use, distribution, and reproduction in any medium, provided you give appropriate credit to the original author(s) and the source, provide a link to the Creative Commons license, and indicate if changes were made.

\section{References}

Aerts L (1999) Sponge-coral interactions on Caribbean reefs. Tesis de $\mathrm{PhD}$, Universidad de Amsterdam, Amterdam, Holanda

Arnold SN, Steneck RS (2011) Settling into an increasingly hostile world: the rapidly closing "recruitment window" for corals. PLoS One 6(12):e28681

Arnold SN, Steneck RS, Mumby PJ (2010) Running the gauntlet: inhibitory effects of algal turfs on the processes of coral recruitment. Mar Ecol Prog Ser 414:91-105

Aronson RB, Precht WF, Toscano MA, Koltes KH (2002) The 1998 bleaching event and its aftermath on a coral reef in Belize. Mar Biol 141:435-447

Bell JJ, Davy SK, Jones T, Taylor MW, Webster NS (2013) Could some coral reefs become sponge reefs as our climate changes? Glob Change Biol 19:2613-2624

Bingham BL, Young CM (1991) Influence of sponges on invertebrate recruitment: a field test of allelopathy. Mar Biol 109:19-26

Birrell CL, McCook JL, Willis BL (2005) Effects of algal turfs and sediment on coral settlement. Mar Poll Bull 51:408-414

Carballo JL, Ávila E (2004) Population dynamics of a mutualistic interaction between the sponge Haliclona aerulea and the red alga Jania adherens. Mar Ecol Prog Ser 279:93-104

Carballo JL, Bautista E, Nava H, Cruz-Barraza JA, Chavez JA (2013) Boring sponges, an increasing threat for coral reefs affected by bleaching events. Ecol Evol 3:872-886

Caselle JE, Warner RR (1996) Variability in recruitment of coral reef fishes: the importance of habitat at two spatial scales. Ecol 77:2488-2504

Chadwick NE, Morrow KM (2011) Competition among sessile organisms on coral reefs. In: Dubinsky Z, Stambler N (eds) Coral reefs: an ecosystem in transition. Springer, Dordrecht. pp 341-371

Chaves-Fonnegra A, Zea S (2007) Observations on reef coral undermining by the Caribbean excavating sponge Cliona delitrix (Demospongiae, Hadromerida). In: Custódio MR, Lôbo-Hajdu G, Hajdu E, Muricy G (eds) Porifera research: biodiversity, innovation and sustainability. Série Livros 28. Museu Nacional, Rio de Janeiro, pp 247-254

Chaves-Fonnegra A, Riegl B, Zea S, Lopez JV, Smith T, Brandt M, Gilliam DS (2018) Bleaching events regulate shifts from corals to excavating sponges in algae-dominated reefs. Glob Change Biol 24:773-785

Darling ES, Alvarez-Filip L, Oliver TA, McClanahan TR, Cote IM (2012) Evaluating life-history strategies of reef corals from species traits. Ecol Lett 15:1378-1386

De Bakker DM, Webb AE, Van Den Bogaart LA, Van Heuven SM, Meesters EH, Van Duyl FC (2018) Quantification of chemical and mechanical bioerosion rates of six Caribbean excavating sponge species found on the coral reefs of Curaçao. PLoS One 13:e0197824

Eakin CM, Morgan JA, Heron SF et al (2010) Caribbean corals in crisis: record thermal stress, bleaching, and mortality in 2005 . PLoS One 5:e13969

Easson CG, Slattery M, Baker DM, Gochfeld DJ (2014) Complex ecological associations: competition and facilitation in a sponge-algal interaction. Mar Ecol Prog Ser 507:153-167

Edmunds PJ, Nozawa Y, Villanueva RD (2014) Refuges modulate coral recruitment in the Caribbean and the Pacific. J Exp Mar Bio Ecol 454:78-84

Edmunds PJ, Steneck R, Albright R, Carpenter RC, Chui APY, Fan TY, Harii S, Kitano H, Kurihara H, Legendre L, Mitarai S, Muko S, Nozawa Y, Padilla-Gamino J, Price NN, Sakai K, Suzuki G, Van Oppen MJH, Yarid A, Gates RD (2015) Geographic variation in long-term trajectories of change in coral recruitment: a global-tolocal perspective. Mar Freshw Res 66:609-622

Engel S, Pawlik JR (2000) Allelopathic activities of sponge extracts. Mar Ecol Prog Ser 207:273-281

Freeman CJ, Thacker RW (2011) Complex interactions between marine sponges and their symbiotic microbial communities. Limnol Oceanogr 56:1577-1586

Gleason DF, Hofmann DK (2011) Coral larvae: from gametes to recruits. J Exp Mar Bio Ecol 408:42-57

Gochfeld DJ, Schlöder C, Thacker RW (2007) Sponge community structure and disease prevalence on coral reefs in Bocas del Toro, Panama. In: Custódio MR, Lõbo-Hajdu G, Hajdu E, Muricy G (eds) Porifera Research: Biodiversity, Innovation, and Sustainability. Série Livros 28. Museu Nacional, Rio de Janeiro. pp 335-343

Gochfeld DJ, Easson CG, Freeman CJ, Thacker RW, Olson JB (2012) Disease and nutrient enrichment as potential stressors on the Caribbean sponge Aplysina cauliformis and its bacterial symbionts. Mar Ecol Prog Ser 456:101-111

González-Rivero M, Bozec Y-M, Chollett I, Ferrari R, Schönberg CH, Mumby PJ (2016) Asymmetric competition prevents the outbreak of an opportunistic species after coral reef degradation. Oecol 181:161-173

Green DH, Edmunds PJ (2011) Spatio-temporal variability of coral recruitment on shallow reefs in St. John, US Virgin Islands. J Exp Mar Biol Ecol 397:220-229

Green KM, Russell BD, Clark RJ, Jones MK, Garson MJ, Skilleter GA, Degnan BM (2002) A sponge allelochemical induces ascidian settlement but inhibits metamorphosis. Mar Biol 140:355-363

Holbrook SJ, Adam TC, Edmunds PJ, Schmitt RJ, Carpenter RC, Brooks AJ, Lenihan HS, Briggs CJ (2018) Recruitment drives spatial variation in recovery rates of resilient coral reefs. Sci Rep $8: 1-11$

Hughes TP (1994) Catastrophes, phase shifts, and large-scale degradation of a Caribbean coral reef. Science 265:1547-1551

Jackson J, Buss L (1975) Alleopathy and spatial competition among coral reef invertebrates. Proc Nat Acad Sci 72:5160-5163

Kuffner IB, Walters LJ, Becerroo MA, Paul VJ, Ritson-Williams R, Beach KS (2006) Inhibition of coral recruitment by macroalgae and cyanobacteria. Mar Ecol Prog Ser 323:107-117 
Loh T-L, Mcmurray SE, Henkel TP, Vicente J, Pawlik JR (2015) Indirect effects of overfishing on Caribbean reefs sponges overgrow reef-building corals. PeerJ 3:901. https://doi.org/10.7717/peerj .7901

López-Victoria M, Zea S, Weil E (2006) Competition for space between encrusting excavating Caribbean sponges and other coral reef organisms. Mar Ecol Prog Ser 312:113-121

Luter HM, Duckworth AR, Wolff CW, Evans-Illidge E, Whalan S (2016) Recruitment variability of coral reef sessile communities of the far north Great Barrier Reef. PLoS One 11:1-16

Maida M, Sammarco PW, Coll JC (1995) Effects of soft corals on scleracticnian coral recruitment. I: differential allelopathy and inhibition of settlement. Mar Ecol Prog Ser 121:191-202

Maliao RJ, Turingan RG, Lin J (2008) Phase-shift in coral reef communities in the Florida Keys National Marine Sanctuary (FKNMS), USA. Mar Biol 154:841-853

McCook L, Jompa J, Diaz-Pulido J (2001) Competition between corals and algae on coral reefs: a review of evidence and mechanisms. Coral Reefs 19:400-417

Morrow KM, Bromhall K, Motti CA, Munn CB, Bourne DG (2017) Allelochemicals produced by brown macroalgae of the Lobophora genus are active against coral larvae and associated bacteria, supporting pathogenic shifts to Vibrio dominance. Appl Environ Microbiol 83:e02391-02396

Morse DE, Hooker N, Morse ANC, Jensen R (1988) Control of larval metamorphosis and recruitment in sympatric agariciid corals. J Exp Mar Biol Ecol 116:193-217

Mundy CN (2000) An appraisal of methods used in coral recruitment studies. Coral Reefs 19:124-131

Nemeth RS, Nowlis JS (2001) Monitoring the effects of land development on the near-shore reef environment of St. Thomas, USVI. Bull Mar Sci 69:759-775

Norström AV, Nyström M, Lokrantz J, Folke C (2009) Alternative states on coral reefs: beyond coral-macroalgae phase shifts. Mar Ecol Prog Ser 376:295-306

Pawlik JR (2011) The chemical ecology of sponges on Caribbean reefs: natural products shape natural systems. Bioscience 61:888-898

Pawlik JR, Steindler L, Henkel TP, Beer S, Ilan M (2007) Chemical warfare on coral reefs: sponge metabolites differentially affect coral symbiosis in situ. Limnol Oceanogr 52:907-911

Porter JW, Targett NM (1988) Allelochemical interactions between sponges and corals. Biol Bull 175:230-239

Qian P-W, Xu SY (2012) Antifouling activity of marine natural products. In: Fattorusso E, Gerwick WH, Taglialatela-Scafati O (eds) Handbook of marine natural products. Springer, New York, pp 749-821

Ritson-Williams R, Arnold SN, Fogarty ND, Steneck RS, Vermeij MJ, Paul VJ (2009) New perspectives on ecological mechanisms affecting coral recruitment on reefs. Smithsonian Contrib Mar Sci 38:437-457

Ritson-Williams R, Arnold S, Paul VJ, Steneck RS (2014) Larval settlement preferences of Acropora palmata and Montastraea faveolata in response to diverse red algae. Coral Reefs 33:59-66

Ritson-Williams R, Arnold S, Paul VJ (2016) Patterns of larval settlement preferences and post-settlement survival for seven Caribbean corals. Mar Ecol Prog Ser 548:127-138

Rogers CS, Fitz HC, Gilnack M, Beets J, Hardin J (1984) Scleractinian coral recruitment patterns at Salt River submarine canyon, St. Croix, US Virgin Islands. Coral Reefs 3:69-76

Rützler K (2002) Impact of crustose clionid sponges on Caribbean reef corals. Acta Geol Hispánica 37:61-72

Sabine A, Smith TB, Williams DE, Brandt ME (2015) Environmental conditions influence tissue regeneration rates in scleractinian corals. Mar Pollut Bull 95:253-264
Slattery M, Gochfeld DJ (2012) Chemical interactions among marine competitors, and host- pathogens. In: Fattorusso E, Gerwick WH, Taglialatela-Scafati $\mathrm{O}$ (eds) Handbook of marine natural products. Springer, New York, pp 823-859

Smith TB, Nemeth RS, Blondeau J, Calnan JM, Kadison E, Herzlieb S (2008) Assessing coral reef health across onshore to offshore stress gradients in the US Virgin Islands. Mar Pollut Bull 56:1983-1991

Smith TB, Brandt ME, Calnan JM, Nemeth RS, Blondeau J, Kadison E, Taylor M, Rothenberger P (2013) Convergent mortality response of Caribbean coral species to seawater warming. Ecosphere 4:87

Smith TB, Ennis RS, Kadison E, Nemth RS, Henderson L (2016) The United States Virgin Islands Territorial Coral Reef Monitoring Program. Year 16 Annual Report. Version 1289 pp. (Available at: https://sites.google.com/site/usvitcrmp/tcrmp-reports)

Sullivan B, Faulkner DJ, Webb L (1983) Siphonodictine, a metabolite of burrowing sponge Siphonodictyon sp. that inhibits coral growth. Science 221:1175-1176

Sutherland JP, Karlson RH (1977) Development and stability of the fouling community at Beaufort, North Carolina. Ecol Monog 47:425-446

Trautman DA, Hinde R (2001) Sponge/algal symbioses: a diversity of associations. In: Seckbach J (ed) Symbiosis. Cellular origin, life in extreme habitats and astrobiology, vol 4. Springer, Dordrecht, pp 521-537

Urvoix LEA, Fauvelot C, Bouchon C (2013) Monitoring of coral larval recruitment on artificial settlement plates at three different depths using genetic identification of recruits (Guadeloupe Island). In: Proc 65th Gulf Caribb Fish Inst 114-120

Vermeij MJA (2006) Early life-history dynamics of Caribbean coral species on artificial substratum: the importance of competition, growth and variation in life-history strategy. Coral Reefs 25:59-71

Vermeij MJA, Smith JE, Smith CM, Vega Thurber R, Sandin SA (2009) Survival and settlement success of coral planulae: independent and synergistic effects of macroalgae and microbes. Oecol 159:325-336

Webster NS, Smith LD, Heyward AJ, Watts JEM, Webb RI, Blackall LL, Negri AP (2004) Metamorphosis of a scleractinian coral in response to microbial biofilms. Appl Environ Microbiol 70:1213-1221

Whalan S, Webster NS (2014) Sponge larval settlement cues: the role of microbial biofilms in a warming ocean. Sci Rep 4:4072. https ://doi.org/10.1038/srep04072

Wilkinson C, Cheshire A (1990) Comparasion of sponge populations across the Barrier Reefs of Australia and Belize: evidence for higher productivity in the Caribbean. Mar Ecol Prog Ser 67:285-294

Wulff JL (2006) Ecological interactions of marine sponges. Can J Zool $84: 146-166$

Wulff J (2012) Ecological interactions and the distribution, abundance, and diversity of sponges. Adv Mar Biol 61:273-344

Zea S (1993) Recruitment of Demosponges (Porifera, Demospongiae) in rocky and coral reef habitats of Santa Marta, Colombian Caribbean. Mar Ecol 14:1-21

Publisher's Note Springer Nature remains neutral with regard to jurisdictional claims in published maps and institutional affiliations. 